\title{
MALAYSIA-CHINA RELATIONS: THE WINDS OF CHANGE IN THE EARLY SEVENTIES
}

\author{
Ahmad Mokhtar Selat
}

\begin{abstract}
Malaysia's foreign policy from 1957-1970 was essentially pro-West and anti-Communist. The People's Republic of China (PRC) was perceived as a threat to the security of the young nation. This policy experienced a shift when Tun Razak succeeded Tunku Abdul Rahman as Prime Minister in 1970. The transformations, besides differing perception among the new political elite, were also caused by changes from within and without. This article analyses those factors as well as the precautions taken by Malaysia, to ensure its security, when it decided to establish relations with the PRC in 1974.
\end{abstract}

Keywords: Bipolar, tri-polar, non-aligned, one-China, two-China, rapprochement, detente, government-to- government, people-topeople.

\section{INTRODUCTION}

The racial riot that took place on 13 May 1969 was an important landmark in Malaysia's modern history. Following the bloody incident, a state of Emergency was declared. Parliamentary democracy was suspended and Tun Abdul Razak, the Deputy Prime Minister, became the Director of the National Operations Council (NOC).

The May 13 incident hastened changes in the political leadership. Pressures emerged from the 'young Turks' within the ruling United Malays National Organisation (UMNO) for Tunku Abdul Rahman, the first Prime Minister of Malaysia, to resign as premier and president of the UMNO. He was perceived to be too soft towards the Chinese. The Tunku was also badly shaken by the tragedy. He admitted that: ${ }^{1}$

All my work to make Malaysia a happy and peaceful country through these years, and also my dream of being the happiest Prime Minister in the world were also going up in flames. 
Following the resignation of the Tunku in September 1970, parliamentary government was restored and the NOC dissolved. Tun Abdul Razak became Prime Minister and concurrently Minister of Foreign Affairs. He appointed his trusted colleague, Tun Dr. Ismail, as his Deputy as well as Minister of Home Affairs. Ghazali Shafie, the Secretary General of the Foreign Ministry, after resigning from his post was appointed as a Senator and subsequently Minister with Special Functions. The three of them thus became major players in the realigning Malaysia's foreign policy. It is interesting to note that Tun Dr. Ismail was the first Malaysian politician to propose the idea of the neutralization of Southeast Asia, one that was guaranteed by the United States, the Soviet Union and China and to be accompanied by a series of non-aggression treaties among the states of the region, soon after the British announcement in July 1967 to withdraw its military presence from East of Suez by 1971. Tun Dr. Ismail's proposal did not receive any response from the Government of Tunku who was staunchly anti-communist and not averse to neutralism. Thus with the departure of the Tunku, Tun Razak with his new like-minded team was able to reposition Malaysia's foreign policy without any inhibition.

\section{CHANGES IN MALAYSIA'S FOREIGN POLICY}

Indonesia's Konfrontasi against Malaysia to some extent soften Malaysia's staunch anti-communist and pro-West policy. At the initial stage, Indonesia with its propaganda that Malaysia was a 'neocolonialist plot' and the 'tool of Western imperialism' was able to isolate the latter from the Afro-Asian group of nations. In its counteroffensive the newly established Malaysia had to send several 'truth missions' to those countries and to lobby support for its membership in the Non-Aligned Movement (NAM) so as to blunt Indonesia's propaganda from within the group. Malaysia failed in its first attempt to participate at the 1963 NAM Conference in Cairo. This prompted the Tunku to soften his anti-neutralism rhetoric. In a letter to Nasser the Tunku for the first time endorsed the five principles of peaceful coexistence which was reiterated in the Cairo Declaration. ${ }^{2}$ Subsequently, Malaysia stepped-up its lobbying efforts and by the eve of the NAM Conference, scheduled to be held in Algiers in 1964, twenty eight countries had already given their commitment to Malaysia's membership. Unfortunately the Conference was indefinitely postponed due to the coup d'état in Algeria. By the time the NAM Conference 
was held in Lusaka in 1970, Malaysia's membership was more than assured.

The first signal made by Tun Razak of a substantive change in Malaysia's foreign policy was made at the Lusaka Conference, some nine days before he took over the Premiership from the Tunku. There he outlined the goals and principles of Malaysia's new foreign policy: ${ }^{3}$

...with the détente between the two Power Blocs, it is an important responsibility of the Non-Aligned Group to ensure that the interests of the Big Powers do not converge at the expense of the medium and small powers...[T]he world today is at least tripolar with the emergence of China onto the international stage...China and her legitimate role in the world cannot be simply washed away by those who are opposed to her...[T] he non-aligned countries have an important role to play...to bring about the harmonization of international relations on the basis of respect for the independence and integrity of states.

While expressing his concern on the Vietnam War and the security of Southeast Asia he emphasized that: ${ }^{4}$

It is my hope that in reaffirming the right of selfdetermination and non-interference in the Indo-China area, the Non-Aligned Group would at the same time take a positive stand in endorsing the neutralization of the area and possibly of the entire region of Southeast Asia, guaranteed by the three major powers, the People's Republic of China, the Soviet Union and the United States.

Thus the Lusaka Conference marked the official launching of Malaysia's proposal to create a 'Zone of Peace, Freedom and Neutrality' (ZOPFAN) which was first proposed by Tun Dr. Ismail in 1968, when he was a backbencher in the Malaysian parliament. It should be noted that in its subsequent pronouncements on ZOPFAN, Malaysia continuously emphasized the need for China to be brought into the mainstream of world politics, a stark departure from the Tunku's pro-West policy of isolating China. For example at the 1970 United Nations General Assembly, Tun Dr. Ismail reiterated that: ${ }^{5}$ 
The world today is no longer bi-polar. It is at least tripolar. Specifically I am referring, of course, to the People's Republic of China, whose absence from this Organisation reflects a serious shortcoming of the UN...The denial to a big power of its proper role cannot be conducive to the establishment of a stable and harmonious world order. I ... wish to reiterate ... my Government's call for ... neutralization ... guaranteed by the ... PRC, the Soviet Union and the United States.

At the Commonwealth Heads of Government Meeting in Singapore in 1971, Tun Razak again reminded the international community of the disadvantage of excluding China from the mainstream of international politics. Such action, he said resulted in China not accepting the existing international order. To Malaysia, there was room for adjustment and accommodation provided that China does not interfere in its internal affairs. ${ }^{6}$

At the Meeting of ASEAN Foreign Ministers in Kuala Lumpur in 1971, after an enormous effort of personal diplomacy, finally Tun Razak managed to persuade all his five ASEAN counterparts to adopt the ZOPFAN Declaration stating that the 'neutralization of Southeast Asia' was a 'desirable objective' and that they should 'explore ways and means' of realizing it. ${ }^{7}$ The reasons for the initial reluctance of the five member countries to endorse the concept then were varied. Thailand and the Philippines were allied to the United States and had American bases in their territories; Indonesia had reservations on China's role in guaranteeing the security of the region because of its experience with the Chinese-inspired coup of 1965; Singapore was uneasy with the Guam Doctrine and the Declaration might further erode the presence of the United States in the region. Nevertheless, the Declaration was an important landmark in Malaysia-China relations as well as ASEAN-China relations as it gave recognition to China's role in the region in the maintenance of peace and security in the despite their non-recognition of Beijing.

\section{External Factors}

The changes in the international system from dual-polar to multipolar were one of the realities that Malaysia had to accept. However it was 
the end of Konfrontasi, the announcement made by Britain in 1967 to withdraw its military forces from East of Suez, the ascendancy of Richard Nixon in 1969 which brought about the dramatic about-turn in American policy, namely the Guam Doctrine and the beginning of American withdrawal from Vietnam, and the signals given by Nixon to normalize relations with China, that provided the catalyst for change.

Tun Dr. Ismail soon after the Bangkok peace talks that ended Konfrontasi in May 1966, when speaking at the Foreign Correspondents' Association, indicated the nature of the changes by outlining what should be done by the Southeast Asian countries to face the new reality: ${ }^{8}$

We look forward for the day when outside powers... accept our right as a region and as constituent nations of this region, to sustain our distinctive ways of life in freedom and prosperity without interference...we do not oppose the communist system in mainland China so long as it confines itself within its own borders....We look forward to a regional association embracing Thailand, Burma, Indonesia, Singapore, Malaysia, Philippines, Cambodia, Laos and Vietnam....Such a community would not be a military alliance...nor...an anti-western alliance. I... envisage an organization which would be first and last, proSoutheast Asia, pro-development, pro-regional cooperation and pro-peace.

The rapprochement with Indonesia and the formation of ASEAN removed the most immediate threat from Malaysia's most populous neighbour. ASEAN provided a code of conduct for the member countries in managing their relations. This fear was further allayed with the signing of the Malaysia-Indonesia Friendship Treaty of 1970 which intrinsically was just one notch below a non-aggression pact, Article 3 of the Treaty states: ${ }^{9}$

The two High Contracting parties undertake that in case any dispute on matters directly affecting them should arise they will not resort to the threat or use of force and shall at all times endeavour to settle such a dispute through the 
usual diplomatic channels in the true spirit of friendship and goodwill between neighbours.

Britain's announcement to withdraw from east of the Suez naturally had far-reaching consequences on Malaysia, which hitherto depended on Britain for its external defence. It had to look for an alternative defence arrangement. This culminated in the Five Power Defence Arrangement (FPDA) involving Malaysia, Singapore, Britain, New Zealand and Australia. The Joint Communique issued in London on $16^{\text {th }}$ April 1971, the five countries agreed that "in the event of any form of armed attack against Malaysia or Singapore" the Government of the five countries "would immediately consult together for the purpose of deciding what measures should be taken jointly or separately in relation to such an attack or threat."10

To Malaysia, the FPDA was not a satisfactory arrangement as it differed markedly from the Anglo-Malaya Defence Agreement (AMDA) under which Britain gave an explicit defence guarantee against external aggression. The FPDA was a loose framework subject to consultation. Thus it dawned on the Malaysian leaders that they could no longer depend on Britain or its Commonwealth allies. This apprehension was felt by Malaysia right from the commencement of the of the FPDA talks. Australia for instance was only willing to commit itself for the defence of 'Malaya' as it did not wish to be involved in the Malaysia-Philippines dispute over Sabah. ${ }^{11}$

The British decision to pull out from the East of Suez was followed by the Nixon Doctrine of disengagement from Southeast Asia. The reduction in American commitment to the defence of the region plus the loosening of its containment of China, which resulted in the historic visit of Nixon to China in February 1972, further prompted Malaysia to find a more viable alternative to ensure its security. The proposal initiated by Malaysia for the creation of a 'zone of peace, freedom and neutrality' in Southeast Asia 'free from any form or manner of interference by outside powers' ${ }^{\prime 2}$ and to be guaranteed by the superpowers should be viewed within this context.

Malaysia's changing policy and its call on the international community to restore China's legitimate role in regional and world affairs naturally became a matter of interest to the Chinese leaders. They were quick to respond to Malaysia's diplomatic move as it 
provided them with an opportunity to have links with ASEAN. It should be noted that as compared to its rivals in the region, the United States and the USSR, China was the only power that did not have diplomatic and official commercial links with any of the ASEAN countries. Its relation with Indonesia was severely damaged when the 'New Order' government of Soeharto accused China of being directly involved in the attempted coup of 1965. The Chinese Embassy was burnt down by rioters and Indonesia broke diplomatic relations with the PRC.

In May 1971, Malaysia made its breakthrough to China. Tengku Razaleigh Hamzah, in his capacity as Chairman of PERNAS (National Trading Corporation) and Chairman of the Associated Malaysian Chamber of Commerce, led a 19-member of multi-racial trade delegation to Beijing for an 'unofficial visit' in response to a joint invitation by the China Export Commodities (Spring) Fair and the National Foreign Trade Corporation. Though treated as 'unofficial', the visit had the full blessing of the Government. Tun Razak himself confidently considered it as the beginning of a 'people-to- people relationship'. ${ }^{13}$ That Tengku Razaleigh led the delegation was politically significant too. He was then the rising star in UMNO and had been specially handpicked by Tun Razak to head PERNAS and Bank Bumiputra, two economic institutions that were tasked to assist the Malays in trade, commerce and industries. Members of the trade delegation were well briefed by the Government agencies, particularly the Ministry of Foreign Affairs and the Special Unit of the Prime Minister's Department, which dealt with security issues. That four government officials were included as advisers to the delegation lend credence to the importance given by the Government to the visit. Dato' Y.T. Lee, a member of the delegation, perhaps inadvertently, before his departure told the press that "if there is an opportunity we shall open the subject of the neutralization policy... and get the reaction of China." 14 The delegation was given such opportunity when Zhou Enlai, in an unscheduled programme, met Tengku Razaleigh. The meeting was highly significant because it was the first ever held by a top ranking Chinese political leader with a Malaysian politician. What transpired was told to the press by Razaleigh in the following words: ${ }^{15}$

He [Zhou Enlai] informed us that he followed the statement made by Tun Abdul Razak on the concept of neutrality, and 
told us that it was also the policy of China to maintain a policy of non-interference and mutual respect for territorial sovereignty and integrity. I could only feel or think that this reaction to neutrality was quite favourable.

Zhou also requested Tengku Razaleigh to convey to Tun Razak that China had no intention of interfering in Malaysia's internal affairs on behalf of insurgents, immigrants or any other group. ${ }^{16}$ After being briefed by Tengku Razaleigh, Tun Razak enthusiastically expressed his view that China's response: ${ }^{17}$

...to our policy (neutralization of Southeast Asia) together with the policy of non-interference in the internal affairs and her recognition of the sovereignty and independence of other nations is very encouraging... The words of Zhou Enlai bear great significance to the countries in this region....I am confidents that the success of the Malaysian trade mission will pave the way to a better relationship between the two countries and their people.

The second visit from Malaysia that was politically significant was the one led by Tan Sri Raja Mohar, a top civil servant and Economic Adviser to the Prime Minister, in November 1972, also guised as a Trade Mission. Zhou Enlai met Raja Mohar and broached two issues that were of paramount importance to Malaysia before normalization could take place. Zhou assured Malaysia that China considered all overseas Chinese who have taken up foreign citizenship as having forfeited their Chinese nationality. With regard to the activities of the CPM, China viewed the issue as Malaysia's own domestic problem. As a sovereign and independent state Malaysia was free to deal with them. He also assured that China did not believe in exporting its revolution or exploiting the sentiments of the overseas Chinese to create political instability because such acts were tantamount to sabotage and impermissible in conducting relations among sovereign nations. ${ }^{18}$ The message from Zhou was very comforting to the Malaysian political elite as these two issues, if remained unaddressed, would invite opposition to rapprochement, especially among the Malays.

China's signal of warming up was reflected in the reduction of propaganda against the Malaysian government in addition to the usage 
of the name 'Malaysia' instead of 'Malaya', thereby giving implicit recognition to Malaysia which it refused to recognise on $16^{\text {th }}$ September 1963, the despatch of a Hong Kong-based dance troupe to raise funds for the 'great flood' in 1970, a tour that could never had taken place during the Premiership of Tunku. This series of confidence-building measures were further strengthened by the Chinese 'ping-pong' diplomacy and the consolidation of power by the 'old guards' in the aftermath of the 'Cultural Revolution'. These development further reinforced Razak's growing confidence in China's commitments to peaceful co-existence with all states irrespective of ideology.

\section{Internal Factors}

The 1969 racial riot brought to the fore the bitter reality that national unity was far from being achieved. The government felt that there was a need to improve the economic well-being of the indigenous people, as one of the main reasons of the racial riot in May 1969, was prompted by the Malay feeling of economic backwardness. To achieve national unity, there was a dire need to strengthen the loyalty of the Chinese and Indians. Several measures were taken by the government to achieve these goals. Among them were the adoption of a new development strategy, the New Economic Policy (NEP) and the promulgation of the 'Rukun Negara' (National Ideology). However what was left unsaid was the centripetal influence of China on the loyalty of the Malaysian Chinese. India posed no problem to Malaysia's effort as the Indian government had abandoned the dual nationality principle even before Merdeka (Independence) Day. Furthermore the Indian population of Malaysia was small as compared to the Chinese and Malays. Thus to effectively overcome the 'Chinese problem' the Malaysian political elite felt that it was imperative to have diplomatic relations with China. Though this fact was not explicitly stressed when Malaysia made public its policy of rapprochement, the issues pertaining to the citizenships of the Malaysian Chinese and the support of the Chinese government to CPM were those insisted by Malaysia be ironed out with the Chinese at the pre-negotiation stage in New York. ${ }^{19}$ China, on the other hand, wanted recognition first and the rest be negotiated at a later stage. 


\section{ONE CHINA OR TWO-CHINA POLICY?}

The change in Malaysia's attitude towards China was correspondingly reflected in all its policy statements, though in gradual and incremental manner. It is pertinent to note that at the 1966 United Nations General Assembly (UNGA), Malaysia emphasized that while China could be represented at the UN but Taiwan should be given the right to remain as a member. ${ }^{20}$

However when Tun Razak assumed the Premiership in 1970 the above stand was abandoned. When he made his major foreign policy announcement in Parliament in July 1971, he cautiously declared that Malaysia was following a one-China policy "on the understanding that the right of the people of Taiwan to decide their own future for themselves should not be denied to them." 21

Tun Razak did not want to commit Malaysia without gauging international opinion concerning the future of Taiwan. However by September 1971 when the UN started it Annual General Assembly (UNGA), Malaysia saw the changing mood of the international community and adjusted its policy accordingly. Its statement on the future of Taiwan became more forthright. Tan Sri Zaiton, then the Secretary General of the Foreign Ministry, at a special briefing entitled 'Malaysia's Policy on China', clearly stated that: ${ }^{22}$

We subscribe not to a two-China policy or a one-China one-Taiwan policy but rather I say this quite categorically to a one-China policy... [T] he problem of Taiwan...is essentially one for the Chinese people to decide...We do not wish to involve ourselves in the minutiae of the Chinese problem. We recognise that the problem of Taiwan is a problem that must be sorted out by the Chinese people.

Subsequently Malaysia voted for China's admission to the UN and the unseating of Taiwan. Malaysia's Permanent Representative to the UN in his explanation before the vote explained that Malaysia would vote in favour of the resolution because "the Government of the PRC is de jure and de facto the Government of China and that it alone has the legitimate right to represent China and occupy China's seat in our Organisation. ${ }^{23}$ Malaysia skirted the thorny question of Taiwan by treating it "as a separate issue which has to be resolved by the parties 
concerned." ${ }^{24}$ Malaysia made its explanation with the objective of swinging the voting pattern of the small developing countries and to clarify its stand on Taiwan despite pressure from the United States. It should be noted that only Malaysia and Singapore were the two ASEAN countries that gave unqualified support for China's admission, a fact that was well taken note of by Beijing until today.

\section{NORMALISATION OF RELATIONS: THE OBSTACLES}

Despite the breakthrough in 1971 and the euphoria caused by USChina détente negotiation for normalization of diplomatic relations began only in June 1973. Malaysia felt that assurances alone could not easily overcome the "accumulation of years of bitterness, frustration and fear." ${ }^{25}$ Thus right from the point when Malaysia gave the signals to China, Tun Razak assured the Malaysian public and his ASEAN colleagues that "we will need to move step by step, feeling our way carefully in matters which so far as the countries of Southeast Asia are concerned, involve our very survival." ${ }^{26} \mathrm{He}$ further emphasized that "we should keep one another informed of developments in regard to our official contact with China in order to ensure that we act as a group on the question of having diplomatic relations." ${ }^{27}$

Among the considerations that made Tun Razak to move 'step by step' were Malaysia's twelve-year struggle during the Emergency against the predominantly Chinese CPM, the refuge given to the CPM leaders in China, the daily dosage of hostile propaganda from the Suara Revolusi Malaya (Voice of the Malayan Revolution) which was operated by the CPM from China and the experience faced by Indonesia and Myanmar of Chinese interference when dealing with their local Chinese population. At the same time words of caution from its ASEAN neighbours also contributed to Malaysia's guarded stand. It is pertinent to note that the ASEAN countries shared common fears as well as problems and they expected Malaysia, as agreed at the 1971 ASEAN Foreign Ministers Meeting, to pave the way to the best political solution pertaining to these problems prior to the establishment of diplomatic relations. ${ }^{28}$

Thus to Malaysia, normalization of relations was not a simple exercise. It involved both political and security considerations. Tun Razak himself, in announcing Malaysia's 'one China' policy 
specifically assured the people that the questions of China's support to the underground movement of the CPM, the hostile propaganda carried by the Suara Revolusi Malaya and the presence of the leaders of the so called 'Malayan Liberation Movement' in China should be 'considered and resolved' before the establishment of diplomatic relations. ${ }^{29}$ On the issue of Taiwan, which was of political importance to China, Malaysia had no problem in conceding to China's requirement. Even at the time of establishing its Consulate in Taipei in 1965, Malaysia made it amply clear that there was a difference between the opening of a Consulate and the setting up of an Embassy. ${ }^{30}$ The Consulate was established purely to look after trade, investment and Malaysian students studying in Taiwanese universities and in no way meant Malaysia's diplomatic recognition. Thus Tun Razak could, with ease, made a clear statement at the 1971 United Nations General Assembly (UNGA) that it was "beyond doubt that the Government of the People's Republic of China was de jure and de facto the Government of China." 31 Consequently when Malaysia formally announced the establishment of Diplomatic relations with China in 1974, the Consulate in Taiwan was closed down with immediate effect. Accordingly the Taiwanese Consulate in Kuala Lumpur was asked to wind its operation. Nevertheless, with the tacit understanding of China, people-to-people relations with Taiwan continued. The Malaysian Airline and the Malaysian Industrial Development Authority (MIDA) continued to maintain their offices in Taipei. They also took over the consular functions of the Consulate that was closed down while Taiwan continued to have informal representation in Kuala Lumpur through its trade office.

Negotiations for normalization finally commenced in New York in June 1973. The first move was made by Malaysia and China responded positively as then it was actively expanding its diplomatic representations in the Afro-Asian countries. The Malaysian delegation was headed by Tan Sri Zakaria Ali and the Chinese by Huang Hua. They were then Permanent Representatives of their respective countries to the United Nations (UN). New York was chosen as the venue because it was the most neutral ground to hold such talks and at the same time would shield the Malaysian public from knowing of what was going on.

The talks were suspended in July 1973 because of China's reluctance to include issues pertaining to the fraternal links between 
the CCP and CPM and the status of the overseas Chinese in the agenda of work. China insisted that the talks should be confined to general principles and that the contentious issues be dealt with after the establishment of diplomatic relations. To Malaysia, the Chinese proposals to merely reaffirm each other's adherence to the basic principle of co-existence were politically unacceptable. Malaysia's insistence was mainly dictated by the presence of a large number of overseas Chinese as its citizens and the China-inspired activities of the illegal CPM. In addition, the Malays that constituted the political base of Tun Razak and his party, UMNO, could never accept the establishment of diplomatic relations without obtaining some form of assurance that China would not interfere in the internal affairs of Malaysia either through the CPM or on the pretext of protecting the rights of its citizens, the overseas Chinese. The stereotypes among the Malays that the Chinese were racially chauvinistic was, still strong then. The memory of the victory procession and the arrogance shown by some of the non-Malays after the 1969 General Election was still fresh in the minds of many Malays. Even UMNO members cautioned the Government at its General Assembly in January 1973 to be wary of the impact of having relations with China. They warned that if the Government were not careful, recognition could make the Malaysian Chinese become 'too proud' a somewhat inaccurate translation of the Malay word 'sombong' which means somewhere between 'proud', 'arrogant' and 'swollen headed'. ${ }^{32}$

\section{REASONS FOR MALAYSIA'S INSISTENCE}

The links maintained by the CPC with the CPM had always been a source of irritation and concern both to the colonial government and the government of independent Malaysia. Leaders of the outlawed CPM were given sanctuary in China and at the propaganda level the CPC never failed to send lengthy congratulatory messages to the CPM on its founding anniversary or to highlight skirmishes against Malaysian security forces. For example on the $40^{\text {th }}$ anniversary of the CPM in 1970, the CPC quoting the teaching of Mao Zedong that 'the people who have triumphed in their revolution should help those still struggling for revolution', reaffirmed its 'internationalist duty' and resolutely supported 'the revolutionary struggle of the Malayan people'. ${ }^{33}$ The messages and the activities of the CPM in smashing the 'suppression' of the 'reactionary authorities' were given prominence by 
the government-run media like the People's Daily and Radio Beijing. In addition, in November 1969 the CPM members in China started broadcasting the 'Voice of the Malayan Revolution' (Suara Revolusi Malaya). ${ }^{34}$ That the subversive calls made by the "Suara Revolusi" were also publicized by the Chinese media did not help to allay the 'suspicion that the station was established with the connivance of the Chinese government. Thus before the establishment of diplomatic relations Malaysia wanted some form of assurance that China would severe its party-to-party relations and cease interfering in Malaysia's internal affairs through the CPM.

With regard to China's attitude towards the status of the overseas Chinese, Malaysia was not the only Southeast Asian country that doubted China's stand. China had always kept this issue vague. The Constitution adopted in 1964 did not dispel the suspicion as it did not contain any Articles that clearly defined who really constituted the citizens of China. ${ }^{35}$ Malaysia therefore needed assurances from the Chinese as it was generally perceived that China's policy towards the overseas Chinese was similar to that of the Kuomintang Nationality Law of 1929 which subscribed to the principle of jus sanguinis. It states that any person born of a Chinese father, or of a Chinese mother where the nationality of the father was unknown or indeterminate, is a Chinese citizen regardless of the place of birth. ${ }^{36}$ Stephen Fitzgerald in his study on China's attitude towards the overseas Chinese also observed: ${ }^{37}$

At no time did the $\mathrm{CCP}[\mathrm{CPC}]$ actually state that it rejected the concept of jus sanguinis on which the Kuomintang law was based; and the evidence suggests that for public purposes at least the Party accepted a very broad interpretation of nationals of the PRC. The criteria on which this interpretation was based were never stated and the outer limits of China's overseas population never defined... [the CPC] ...was prepared to claim the broad undifferentiated mass of Overseas Chinese as nationals... irrespective of their own attitudes or the attitudes of the governments of the countries of residence.

Malaysia's suspicion, and for that matter the suspicions of the other ASEAN countries, was further strengthened by the provisions 
of Articles 23 and 98 of the 1954 Constitution. Article 23 states that the Nationals People's Congress, among others, composed of Chinese who live abroad and Article 98 guarantees that the PRC would protect the just rights and interests of the Overseas Chinese. Thus Malaysia could never leave this issue unresolved lest China would feel justified to interfere in its internal affairs on the pretext of protecting the rights and interests of its nationals. Besides that China had a notorious record of explicitly carrying out subversive activities among the Overseas Chine in Indonesia and Myanmar, ${ }^{38}$ despite the commitment it made in Bandung in 1955 to adhere to the five principles of co-existence. The posture taken by China further entrenched the perception that overseas Chinese were potential 'Fifth Column', ready to be exploited by China for its political and revolutionary goal. Thus, given its big Chinese population and the links maintained by the CPC with the MCP it was imperative for Malaysia to obtain China's stand on the status of the Malaysian Chinese who had taken Malaysian citizenships, the status of the 200,000 stateless Chinese ${ }^{39}$ permanently residing in Malaysia and China's recognition that the CPM was Malaysia's own domestic problem and that the CPC should cease interfering in Malaysia's domestic affairs through the CPM. With regard to the Malaysian Chinese who had taken up Malaysian citizenship, either by their own free will or operation of law, Malaysia wanted China to categorically recognise that they had automatically forfeited their Chinese citizenship. Malaysia insisted that a bilateral agreement should be signed covering these issues. The formula forwarded by Malaysia was unprecedented in diplomacy as establishment of diplomatic relations is normally done in a communique full of diplomatic niceties and does not cover detailed issues related to citizenship, security and the like. Normally those issues would be covered by separate bilateral agreements. Due to the differences in approach the talks came to a standstill in July 1973. Discussions were deferred but lines of communication between the two Permanent Representatives at the UN remained open. They agreed to inform each other should there be new instructions from their respective capitals. It was in an effort to break this deadlock that the Chinese floated the idea of a document short of an agreement to accommodate Malaysia's insistence in October 1973. The Chinese proposed that all the issues would be included in the Joint Communique and to make the difference the document would be signed by both the Heads of Government. Malaysia accepted the proposal as a signed Joint Communique of a great power and a 
permanent member of the UN Security Council could be considered as good as an agreement. Furthermore, if China were to renege on its commitment it would have a deleterious effect on its prospect of normalizing relations with the rest of the ASEAN member countries.

In December 1973, agreement was reach on all the major issues and the draft text of the Joint Communiqué was already in place. A key component of the normalization process was an official visit of Tun Razak to China on the invitation of his counterpart. Tun Razak waited for the opportune moment to announce it, so as to gain as much political mileage at the domestic level. Finally in March 1974 he revealed that "the accord for diplomatic ties will be successfully concluded soon" 40 confirming rampant speculation that he would be visiting China for the occasion. A belated official announcement was made by the Foreign Ministry on $21^{\text {st }}$ May confirming that both the "Governments of Malaysia and the People's Republic of China have agreed in principle to establish full diplomatic relations and that on the invitation from Premier Chou Enlai, Tun Razak would pay an official visit to the PRC from May 28 to June 2, 1974." 41

It is interesting to note that Tun Razak's visit could have taken place much earlier as the agreement on the Joint Communique had been concluded in December 1973. However it was scheduled in such a way as to immediately precede the general elections held in August, the first to be held after 1969 where most of the candidates of the Malaysian Chinese Association (MCA) were humiliatingly trounced by the Chinese dominated Democratic Action Party (DAP) and the Gerakan Rakyat Malaysia (GERAKAN) who in the main claimed that the MCA was neglecting the non-Malays by towing UMNO's policy. Thus the timing of the visit was aimed at propping the image of the MCA and to some extent weakened the perception among the Chinese that Tun Razak was anti-Chinese. In fact during the election campaign, posters of Tun Razak shaking hands with Chairman Mao with the slogan 'Barisan Nasional is for Racial Harmony' were fully exploited by the MCA to win Chinese votes.

\section{OUTCOME OF THE VISIT}

The Joint Communique signed by Tun Razak and Zhou Enlai in essence covered two broad areas. The first dealt with the principles of Sino-Malaysia relations and the second concerned agreements on 
the questions of the nationality of people of Chinese origin residing in Malaysia namely the stateless Chinese and those who had become Malaysian citizens by operation of law, naturalization or registration.

The principles of relations were covered in the operative paragraphs of one to four. They dealt first of all with mutual recognition and the decision of both governments to have diplomatic relations from the date of the signing of the Communique. The second paragraph referred to mutual adherence to the five principles of peaceful co-existence namely mutual respect for sovereignty and territorial integrity, mutual non-aggression, non-interference, equality, mutual benefit and peaceful co-existence. In the third paragraph, China recognized the Government of Malaysia and respect for the independence and integrity of Malaysia while in turn Malaysia recognized the Government of the People's Republic of China and acknowledged that Taiwan was an inalienable part of its territory. There were also basic general principles which Malaysia felt need to be emphasized, hence the inclusion that: ${ }^{42}$

The two governments consider all foreign aggression, interference, control and subversion to be impermissible. They hold that the social system of a country should only be chosen and decided by its own people. They are opposed to any attempt by any country or group of countries to establish hegemony or create spheres of influence in any art of the world.

Malaysia's insistence on the inclusion of this paragraph stemmed from China's reluctance to abandon its party-to-party relations with the CPM. Malaysia hoped that the inclusion of this additional principle would restrict China's link with the CPM. Anything that went beyond moral support could be construed as 'subversion and aggression' and therefore 'impermissible'. Tun Razak at a home welcoming rally from the China visit emphasized the significance of these principles. He stated that: ${ }^{43}$

The...principles have far reaching implications for our internal as well as external affairs. Chairman Mao and Premier Chou [Zhou]...have categorically assured that they regard the remnant terrorists... as our internal problem 
which it is for us to deal with as we think best. The PRC has unequivocally stated that the social system in any country is for the people of that country alone to choose and decide... The struggle of the terrorists [CPM] to impose by force another system which has been rejected by our people is hopeless and futile. The PRC recognizes Malaysia and its independence and sovereignty...The terrorists cannot claim that they are fighting for freedom.

Thus the CPM was Malaysia's own internal problem and it could take any action against them without China's interference. Tun Razak further underscored this point when he told the crowd welcoming him home that Mao Zedong had told him that the CPM "is a matter for you to solve in whatever way you think fit." 44

With regard to the law of nationality both the Governments declared that they did not recognise dual nationality. Based on this principle, in the Joint Communique the PRC emphasized that the "Chinese Government considers anyone of Chinese origin who has taken up of his own free will or acquired Malaysian nationality as automatically forfeiting Chinese nationality." 45 As for the nonMalaysian Chinese residing in Malaysia the Chinese Government "according with its consistent policy, will enjoin them to abide by the law of the Government of Malaysia, respect the customs and habits of the people there and live in amity with them." 46

Malaysia's insistence on the agreement on the issue of nationality was dictated by two main considerations. Firstly' it wanted to remove the possibility of Chinese interference in its internal affairs on the pretext of protecting the interests of its nationals. The majority of the ethnic Chinese were Malaysian citizens and therefore aliens to China, As for those who chose to remain Chinese national, China admitted for them to abide "by the law of the Government of Malaysia," thus removing the possibility of a repeat of the experience faced by Myanmar and Indonesia where Chinese nationals were incited by the Chinese Embassy not to obey local laws on the excuse that they were non-citizens. Secondly, Malaysia needed this definite clarification so that the Chinese in Malaysia would not have any doubts regarding their status and future. Thus when Tun Razak arrived home from China he forthrightly told the Malaysian Chines that: ${ }^{47}$ 
People of Chinese origin who have taken Malaysian nationality are automatically not Chinese nationals. It will therefore be absolutely clear that there would be no future in Malaysia for fence sitters, for people whose loyalties are divided....We are all Malaysians and our ...future... lies ...in Malaysia. As Malaysians we should view our new relationship with the $\mathrm{PRC}$ as a logical development of our foreign policy. The PRC's mission should be regarded as no more than one other foreign mission functioning in Kuala Lumpur.

It was for this reason that the nationality issue dominated most of the schedule of the negotiations in New York and was the main cause of the negotiation being suspended for several months when China insisted that the issue be resolved only after the establishment of formal diplomatic relations. China's reluctance should be viewed within the context of PRC-Taiwan rivalry to gain the allegiance of the overseas Chinese. Since its birth in 1950 PRC had kept the issue ambiguous so that if the need arose the issue could be exploited to its advantage. Thus in the negotiation China preferred to skirt the issue for fear of being accused by Taiwan of having compromised the interests of the overseas Chinese. The deadlock was overcome when China realized that this particular was non-negotiable as far as Malaysia was concerned.

Through the Joint Communiqué Malaysia got nearly all the commitments it wanted from China except an explicit assurance that it would severe its fraternal links with the CPM. Instead, Malaysia obtained a general assurance in the second operative paragraph declaring that "all foreign aggression, interference, control and subversion to be impermissible." ${ }^{48}$ Zhou Enlai in his speech at the banquet honouring Tun Razak in no uncertain term that the "Chinese people consistently support the just struggle of all oppressed nations and peoples. This is our internationalist duty." 49 However in the same speech Zhou Enlai outlined that the support could be moral rather than material when he said that: ${ }^{50}$

We hold at the same time that the social system of a country can only be chosen and decided by its own people and cannot be imposed by other countries. 
Nevertheless Malaysia obtained verbal assurances both from Chairman Mao and Premier Zhou that the CPM was Malaysia's own internal problem. Tun Razak drove home this fact at a special press conference to Malaysian journalists in China. He explained: ${ }^{51}$

Then I brought up the question of the terrorists. The majority of Chinese in Malaysia, of course, are loyal to the country but there is a small group of terrorists which is causing trouble in our country.... The existence of this group may hinder the progress of our diplomatic relations and our good relationship....Chairman Mao said no, this is a matter for you. The terrorists are an internal matter for Malaysia and you can do what you like....

With regard to the future of the 200,000 stateless Chinese residing in Malaysia, China did not make any commitment beyond what was said in the Communique "that they should abide by the law of the Government of Malaysia." Only Tun Razak elaborated on this issue by stating that: ${ }^{.2}$

This matter should be examined after relations have been established. As far as China is concerned, if these people want to become Chinese nationals, China is prepared to issue them with Chinese passports. They say that if these people want to become citizens of China they will accept them.

However after the establishment of diplomatic relations, Malaysia did not pursue the matter further. China was 'not particularly anxious to have them'. ${ }^{53}$ This attitude could be attributed to the lingering antireturnees' sentiment of the Cultural Revolution. Malaysia on the other hand felt that in the long run the problem would die a natural death as the stateless were already quite old. Most of their children had already acquired Malaysian citizenships either by operation of law by operation of law, if one of the parents were Malaysian citizen, or by registration or naturalization. For security reasons, Malaysia also did not want to give an opportunity of the PRC's Embassy access to the local Chinese community. 


\section{CONCLUSION}

Under the premiership of Tun Razak, Malaysia's foreign policy experienced a major transformation. Malaysia became non-aligned and espoused the creation of a zone of peace, freedom and neutrality in Southeast Asia, to be guaranteed by the super powers. To achieve this, it was imperative for Malaysia to recognise China and join the international campaign to restore China's rightful role in international relations. This culminated in Tun Razak abandoning the Tunku's policy of non-recognition and adopted a one-China policy in contrast to the old two-China policy. China's reluctance to totally severe its relation with the CPM caused Malaysia to restrict its relation with China to the Government-to-Government level. Interaction at the social level was subject to government restrictions.

\section{NOTES}

1 Tunku Abdul Rahman, May 13 Before and After, Kuala Lumpur: Utusan Melayu Press, 1969, pp. 93-94.

2 Cited in J. Saravanamuttu, The Dilemma if Independence: Two Decades of Malaysian Foreign Policy, 1957-1977, Penang: Penerbit Universiti Sains Malaysia, 1983, p. 72.

3 Foreign Affairs Malaysia, Vol. 3, No. 2, December 1970, p. 16.

4 Ibid.

5 Ibid.

6 Ibid.

7 For the full text of the ZOPFAN Declaration, see $<\mathrm{http}: / / \mathrm{www}$.aseansec. org/1215.htm>

8 See Far Eastern Economic Review, 4 December 1971, pp. 5-6; and Marvin Ott, The Neutralisation of Southeast Asia, Athens, OH: Centre for International Studies, Ohio University, 1974, pp. 11-29.

9 Cited in Saravanamuttu, The Dilemma of Independence, p. 2.

10 The Straits Times, 24 June 1996.

11 Far Eastern Economic Review, 26 June 1971, p. 690.

12 Ibid.

13 Malaysian Digest, Vol. 3, No. 3, 15 May 1971, p. 1.

14 The Malay Mail, 6 May 1971.

15 The Straits Times, 18 May 1971.

16 Far Eastern Economic Review, 10 June 1974, p. 28.

17 Malaysian Digest, Vol. 3, No. 9, 31 May 1971, p. 1. 
18 Foreign Affairs Malaysia, Vol. 4, No. 1, March 1971, p. 15.

19 Zakaria Mohd. Ali, "Normalisation of Relations with China," in Fauziah Mohamad Taib (ed.), Number One Wisma Putra, Kuala Lumpur: Institute of Diplomacy and Foreign Relations (IDFR), 2006, pp. 119-130.

20 Foreign Affairs Malaysia, Vol. 1, No. 3, December 1966, pp. 23-24.

21 Foreign Affairs Malaysia, Vol. 4, No. 3, September 1971, p. 20.

22 Ibid., pp. 43-44.

23 Foreign Affairs Malaysia, Vol. 4, No. 4, December 1971, p. 13.

24 Ibid.

${ }^{25}$ Foreign Affairs Malaysia, Vol. 4, No. 1, March 1971, p. 15.

26 Ibid.

27 Foreign Affairs Malaysia, Vol. 5, No. 3, September 1972, pp. 113-114.

28 Article 6 of the Communique stipulates that "The ASEAN Foreign Ministers reiterated the necessity of close consultation and cooperation amongst their representatives at regional and international forums so that the members of ASEAN would always present a united stand to advance their common interests."

29 Ibid.

30 Kementerian Luar Negeri, Siaran Akhbar No. 12/65/67, 4 December 1965.

31 Foreign Affairs Malaysia, Vol. 4, No. 4, December 1971, p. 13.

32 Asian Recorder, 11-17 June 1975, p. 10207.

33 Peking Review, 8 May 1970, p. 13.

34 Anthony Short, "Malaysia: Son of Communist Insurrection," Southeast Asian Spectrum, Vol. 4, No. 4, September 1976, p. 7.

35 See Liu Shao Chi, Report on the Draft Constitution of the People's Republic of China, Beijing: Foreign Language Press, 1962.

36 For further details see, Leo Suryadinata, China and the ASEAN States, Singapore: Singapore University Press, 1972, pp. 79-80.

37 Stephen Fitzgerald, China and the Overseas Chinese, Cambridge: Cambridge University Press, 1972, pp. 79-80.

38 For details on Chinese subversive activities in Indonesia, see M. Mozinggo, Chinese Policy toward Indonesia, Ithaca, NY: Cornell University Press, 1976, pp. 157-191.

39 They were categorized as stateless because they were neither citizens of Malaysia nor possessed the legal documents to prove that they were citizens of another country. However, under the principle of jus sanguinis, China could always claim that they were Chinese citizens and therefore entitled to Chinese protection.

40 Foreign Affairs Malaysia, January-March 1974, p. 27. 
41 Malaysian Digest, 30 May 1974, p. 1.

42 "Joint Communique of the Government of Malaysia and the Government of the PRC," <www.china.org.cn/english/2004/May/96837.htm >

43 Pejabat Perdana Menteri, Siaran Akhbar 6/74/11, 2 June 1974.

44 New Straits Times, 3 June 1974.

45 "Joint Communique of the Government of Malaysia and the Government of the PRC."

46 "Joint Communique of the Government of Malaysia and the Government of the PRC."

47 Pejabat Perdana Menteri, Siaran Akhbar 6/74/11, 2 June 1974.

48 "Joint Communique of the Government of Malaysia and the Government of the PRC."

49 Foreign Affairs Malaysia, Vol. 7, No. 7, June 1974, p. 43.

50 Ibid.

51 New Straits Times, 2 June 1974.

52 Ibid.

53 Ibid. 